\title{
A PROPOSAL TO TEACH LIGHT IN A UNIFIED FRAMEWORK USING THE FEYNMAN METHOD
}

\author{
Maria de los Ángeles Fanaro, Maria Rita Otero \\ National University of the Center of the Buenos Aires Province, Argentina \\ E-mail: mfanaro@exa.unicen.edu.ar, rotero@exa.unicen.edu.ar \\ Marcelo Arlego \\ National University of La Plata, Argentina \\ E-mail: arlego@fisica.unlp.edu.ar
}

\begin{abstract}
The goal of this proposal is to teach the basic aspects of light from the point of view of quantum mechanics at high school level. To this end, we have adapted Feynman's Path Integral Method of Quantum Mechanics. This is a continuation of previous works where we considered the quantum behaviour of matter. The situations were to promote the conceptualization of the electron as a quantum system, the probabilistic function and the transition quantum-classic. Now, the goal is to build a new proposal to teach the behaviour of the light from an actual vision and from a unified model: the quantum mechanics, from the reconstruction of a reference that also uses the approach Path Integrals of Richard Feynman. It is adapted for secondary school students using vectors and sums, and it is inserted in a problems context about the light. Careful and accurate language is used, avoiding terms like photon or expressions like particles of light or wave-particle duality, because these ideas could present obstacles to understanding key aspects of quantum theory. This proposal is an alternative to avoid historical approaches commonly used so far and it is being implemented in two groups of students in secondary school (15-16 years old). Key words: Feynman method, light, quantum mechanics, secondary school, teaching.
\end{abstract}

\section{Introduction}

Nowadays Physics teachers have the challenge of teaching the basic concepts of modern Physics in secondary school. The syllabus of many countries (Lobato and Greca, 2005) and the researches in physics education strongly recommend teaching Quantum Mechanics (Cuppari, Rinaudo, Robutti, and Violino, 1997; Fischler and Lichtfeldt, 1992; González, Fernández, and Solbes, 2000; Greca, Moreira and Herscovitz, 2001; Hanc and Tuleja, 2005; Paulo and Moreira, 2004, 2005, Paulo, 2006; Montenegro and Pessoa, 2002; Moreira and Greca, 2000; Müller and Wiesner, 2002; Niedderer, 1997; Olsen, 2002; Osterman and Moreira, 2000; Ostermann and Ricci, 2004; Osterman, Prado, and Ricci, 2006, 2008; Pessoa, 1997; Pinto and Zanetic, 1999; Taylor, Vokos, O'Mearac and Thornberd, 1998; Taylor, 2003). Nevertheless, it is also known that physics teachers are not well prepared to teach QM concepts. Moreover, textbooks usually follow a historical line which we are trying to avoid.

The goal of this investigation is to build a proposal to teach the behaviour of light from the point of view of quantum mechanics. This will range from the reconstruction of a reference framework based on Feynman `s Path Integral approach to its adaptation for secondary school students (Arlego, Fanaro and Otero, 2012, Fanaro, Otero, Arlego, 2012). The Feynman method has been used in previous works for teaching quantum mechanics (Taylor, 1996, Taylor and 


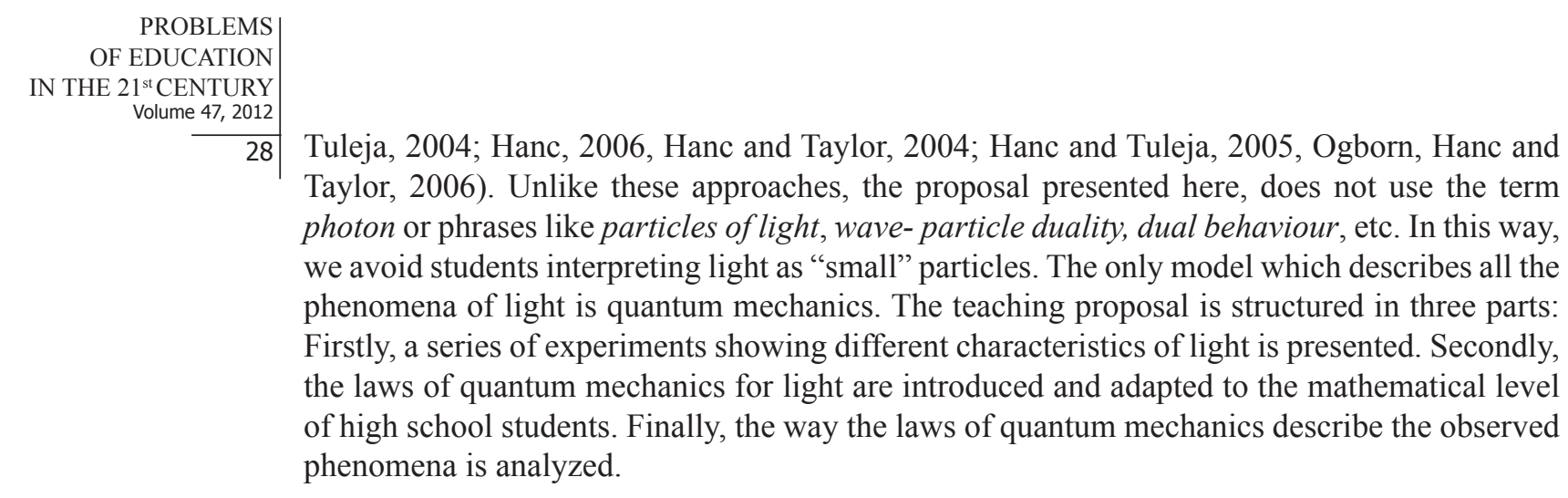

\section{Theoretical Frame}

Secondary and university level teaching have forgotten that knowledge begins with questions; as a result, only answers are taught. Therefore, it is essential to focus on teaching questions and situations as complex tasks in order to teach a "living" science. To that end, some conditions must be accomplished to study meaningful questions at school. These questions should have:

- Cultural and social legitimacy: the questions must be related to the issues considered relevant by society.

- Physical legitimacy: the questions must be related to basic situations in Physics.

- Functional legitimacy: the questions must be related to other issues studied at school, in physics or in other science courses (Bosch, García, Gascón, Ruiz Higueras; 2006).

QM is transformed when it is taught at a given institution; this is the well-known phenomenon of didactic transposition (Chevallard, 1992, 1997, 1999). In Physics, there are many conceptual fields (Verganud, 1990) in which at least one Conceptual Structure of Reference (CSR) can be distinguished and recognized (Otero, 2006). When a Physics teacher invites their students to study a specific conceptual field, he or she adopts more or less explicitly a particular CSR. A CSR is a set of concepts, the relationship between them, the principles, the affirmations of knowledge and the explanations relative to a conceptual field accepted by the scientific community of reference. Our investigation rebuilds a CSR based on Feynman's Paths Integral method (Feynman, 1965). The CSR adopted will be partially or fully reconstructed by a class group or by someone who tries to study it in high school, or in basic and advanced courses at university. Moreover, the researcher in science teaching needs to establish and rebuild a CRS. On the one hand, he needs to analyze the knowledge that lies in the scientific community and, on the other hand, the characteristics, constraints and possibilities offered by the institution where this knowledge will be reconstructed (Otero and Fanaro, 2011).

Any attempt to reconstruct knowledge creates a different conceptual structure for the components and the relationship between them. In a more or less explicit way, each teacher of a certain group will reconstruct or select -based on an existing structure- one conceptual structure to be taught, and, in the best of cases, he or she will invite his or her class to study it. We coined the term Proposed Conceptual Structure for Teaching (PCST) (Otero, 2006) to describe a set of concepts, the relationship between them, the affirmations of knowledge, principles and situations related to a certain conceptual field that the teacher proposes to reconstruct based on a CSR.

There are characteristic structures related to diverse conceptual fields that are alive, adapted and accepted into certain institutions. They survive because they are viable. The design, analysis and rebuilding of a PCST related to QM, viable at high school, is a specifically didactic objective. The structures are systems (components + organization) that include key concepts, like the relationships and fundamental principles that tie them together. 
When the Vergnaud ideas about concepts and conceptualization are adopted, the operating and the predicative form of conceptualization both must be included. The implicit aspects of knowledge are considered by the operating invariants involved in the conservation of the forms to organize the action. This idea of concepts related to action in all their variations makes possible to build a bridge to the underlying emotions and feelings, also included in the conceptual structures. These structures are inseparable from the set of problems and situations that give sense to them. The PCST has the following components:

Teaching Situations: The situations are formulated around strong, personally, socially, scientifically, and institutionally relevant questions. The answers to give are provisional, not immediate, they require a lot of time, and, above all, they do not finish in formal schooling. The situations must be developed considering the scientific knowledge, the students' knowledge and the expected learning outcomes. The students' knowledge cannot be ignored by the designed situations. They are the result of a research activity which anticipates and controls their functioning, adaptability and viability. Teaching situations have an explicit didactic intention: they carry out activities concerning physical knowledge construction held by the students and the teacher in the class. The design, implementation and validation of teaching situations are complex processes, characteristic of the research activity in Physics didactic. In these processes students' activity and teachers' activity are analyzed according to a didactic framework, a cognitive framework, or both. In spite of this, it is necessary not to confuse the two ways to evaluate the obtained results.

Key Concepts: These are the main concepts that must be built. They are produced in the proposed situation and without them the posed problem cannot be resolved. The Vergnaud's ideas of concepts are assumed. Concepts are a short list of situations, OI and referents (symbolic representations).

Key Questions: The situations proposed by the teacher are complex tasks. These situations and their derived questions will be discussed by the CG. The situations resolution calls for specific concepts that will be constructed answering the questions.

Emotions: Emotions are dynamic body dispositions determining our action domain (Maturana, 1995). Our conversations affect our emotions and our emotions affect our conversations. The PCST invites the students to enter upon a knowledge domain, where the denial of the other one is avoided, and an appropriate emotional dynamics to knowledge construction is built. One of the main teacher actions comes from acceptance regarding the students' knowledge, ideas, conceptions, and room for students' learning activities.

Actions: They comprise three dimensions: the biological, mental and acting dimension. In the PCST the last dimension is stressed. The teacher and students' actions related to knowledge are of the interest of this research. It is necessary to anticipate which actions are suitable for the knowledge domain that has been built. The different meanings of these concepts flow from the system of actions related to them in every domain and situation.

Symbolic representations: They refer to the external representation, verbal and not, used in language and the systems of symbols used to talk and write about scientific concepts of every knowledge domain.

The PCST design is a complex process that requires multiple actions and decisions related to the concepts and principles that could be studied. Which questions and problems would be more suitable for the conceptualization? What kind of inferences could the students make? What actions and activities does it hope that the students do? The PCST design involves:

- Analyzing and selecting the key concepts of the conceptual field that will be reconstructed in the class group (CG);

- Creating the appropriate situations and situations that use software simulation

- Choosing the suitable parameters to avoid actions that could mislead the study. 
PROBLEMS

OF EDUCATION

IN THE $21^{\text {st }}$ CENTURY

Volume 47, 2012

The teacher and his CG will indeed reconstruct the PCST in a certain and specific institution generating the Conceptual Structure Effectively Reconstructed (CSER). The CSER is a set of concepts, relationships between them, principles and affirmations of knowledge related to a certain conceptual field reconstructed by the CG. The teacher and the students interact in conversations characterized by an adapted emotional dynamic. Every member of the CG will relate to a personal conceptual structure and a unique network of personal and private meaning. Simultaneously, the conversation in the CG will result in the students creating a network of public and shared meaning. This consensual product is also known as "the process of meaning negotiation". This negotiation process can be more or less explicit and conscientious, depending on the professionalism of the teacher, and the distance between the CSR, the PCST and the CSER.

\section{Teaching Situations of the Proposed Conceptual Structure}

In this part, the Teaching Situations are discussed. It is organized in three stages.

\section{First part: experiments showing different characteristics of light}

The aim of this part of the proposal is to expose the students to some familiar physical experiences in which phenomena of reflection, refraction, and interference of the light are observed. These are presented in a question context for students and simple classroom experiments with mirrors, lenses and double slit experiment with semiconductor lasers.

After that a sequence of real images from the double slit experiment with light of very low intensity is presented to the students. Unlike the previous experience of the double slit, here it is possible to register individual events of detection; the light is detected on the screen in discontinuous form. Initially, the individual events seem to be distributed randomly on the screen. But as time goes the formation of a pattern of maxima and minima, similar to the previous experience, occurs. In this case the light exhibits a behaviour different from the previous experiences. In some aspects it seems to be granular, for instance the individual detection of events on the screen (also the process of emission of the light from the source). But others showing a wave-like character, as the final pattern of alternated maxima and minima formed on the screen. This example shows that it is not possible to assign to the light purely wave or corpuscular aspects, and therefore impossible to reconcile completely with the usual concept of particle or wave. This characteristic of light is called "quantum behaviour" and it also applies to what ordinarily it is consided matter (Fanaro, Otero, and Arlego, 2009).

\section{Second part: the laws of quantum mechanics for light from Feynman approach}

The approach that is proposed to describe the different aspects of light in a unified frame is an adaptation of Feynman's formulation of the sum of all alternatives of quantum mechanics (Feynman, 1985). This method is presented in form of rules: 

as shown in Figure 1a.

Figure: 1a. Possible paths to connect I with F.

2- We associate each possible path with a unitary vector, called "Probability amplitude", whose direction is proportional to the time of travelling from $I$ to $F$. The proportionality constant is the frequency of the light, though we will avoid mentioning this term to the students because it refers to a wave-like model of the light. We will only state that this constant takes different values depending of "types" of light: red, green, etc.

3-All amplitude of probability vectors associated to different paths connecting $I$ with $F$ must be added. We call the resulting vector "total probability amplitude". In Figure 2 (right) the sum is pictorically shown for selected paths (left)
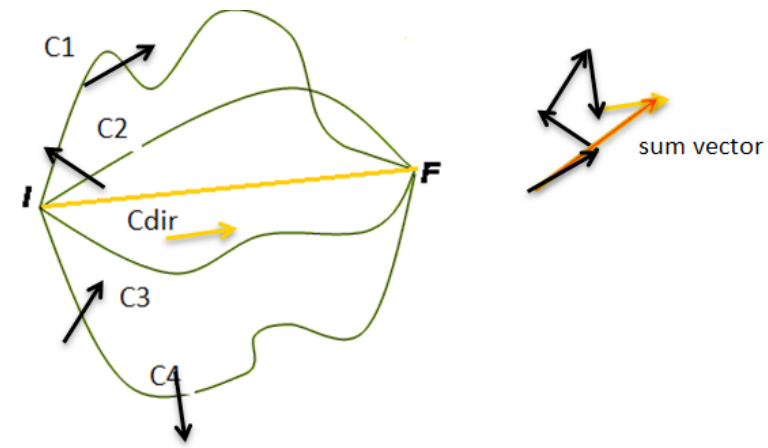

Figure: 2: Associated vectors and their sum.

4- Finally, the square module of the total probability amplitude gives the relative probability of light to be detected at $F$, having been emited at $I$.

\section{Figure 1: Feynman's sum of all paths formulation of quantum mechanics for the light, adapted for high school level.}

In principle all paths connecting initial and final states must be considered in the calculation of the resultanting vector to obtain the probability. This raises the problem of adding infinite vectors. Nevertheless, it is possible calculate this sum aproximatelly in the following way. Figure 2 shows some alternative paths and the graphical sum of the vectors. The resultant vector (green) goes from the beginning of the first one to the end of the last one. As it can be observed, only the paths around the one of least time (straight line D in the figute) make the main contribution to the sum (paths $\mathrm{C}$, and $\mathrm{E}$ in same figure). All the others tend to statistically cancel to each other, and they do not contribute to the sum (A, B, F and G). 
PROBLEMS

OF EDUCATION

IN THE $21^{\text {st }}$ CENTURY

volume 47,2012

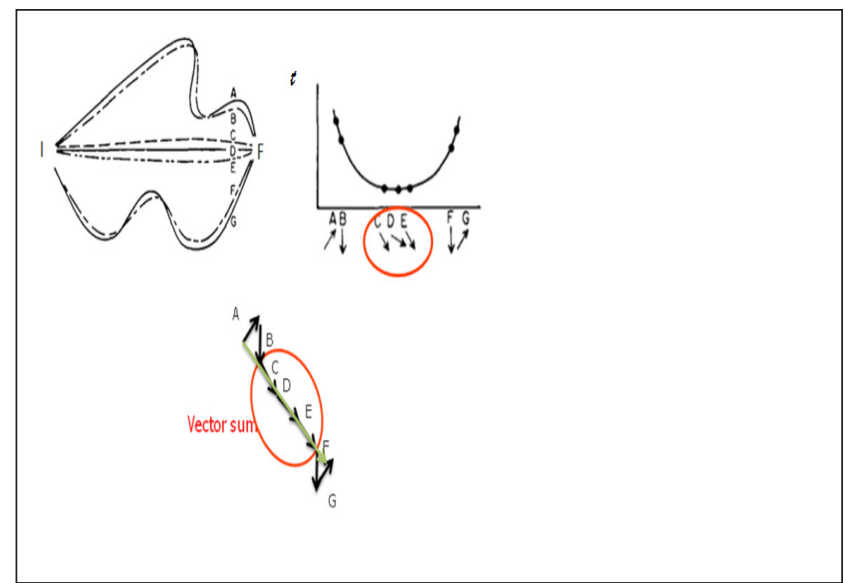

Figure 2: Associated vectors to some possible paths, and their sum. It can be observed that the shortest time and its souround are those which contribute to the sum, and therefore to the probability.

Mathematically, it can be expressed as:

$$
\text { Total Amplitude }(\mathrm{I} \rightarrow \mathrm{F})=N\left(\cos \left(2 \pi f t_{\min }\right) ; \sin \left(2 \pi f t_{\text {min }}\right),\right. \text {, (1) }
$$

where N "counts" the contributions of nearby paths to the straight path, and $f$ is the frequency of the light. A simulation with the software Modellus ${ }^{T M}$ where students can choose different possible paths connecting the initial point to the final point. For each path selected the simulation shows the associated vector, and the students have to make the sum of them to conclude that the most probable path for the light is the straight one, that is to say, the one of least time. Fig. 3 shows a screen captured from this simulation:

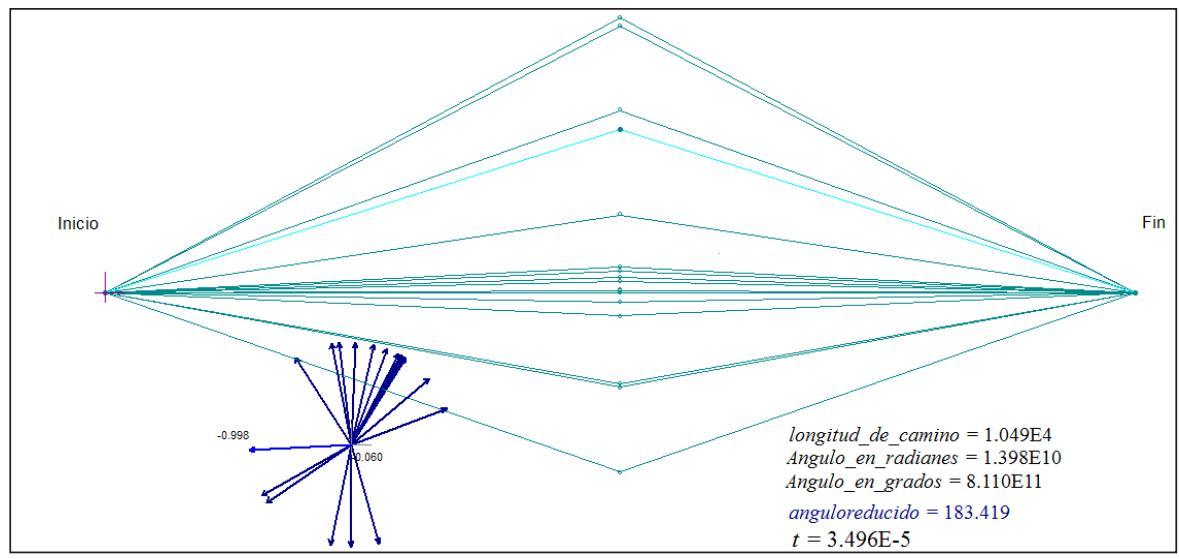

Figure 3: That shows the simulation for the Feynman method to the light travelling form $I$ to $F$.

Third part: the laws of quantum mechanics describe the observed phenomena

Here we describe how Sum of all alternatives method can predict the observed phenomema associated with light, presented in the first part. We will focus on reflection on a mirror, refraction and interference, but the method is applicable in more general and complex situations. 
Maria de los ÁNGELES FANARO, Maria Rita OTERO, Marcelo ARLEGO. A Proposal to Teach Light in a Unified Framework Using the Feynman Method

a) Reflexion of light

\begin{tabular}{l} 
OF EDUCATION \\
IN THE 21 $1^{\text {st }}$ CENTURY \\
Volume 47, 2012 \\
\hline 33
\end{tabular}

From Figure 4 it is possible to analyse with the students different paths connecting $\mathrm{S}$ with $\mathrm{P}$. It is simple to conclude that the most probable path is the one of minimal lenght (or least time). For that path, the angle of incidence is equal to the angle of reflection.

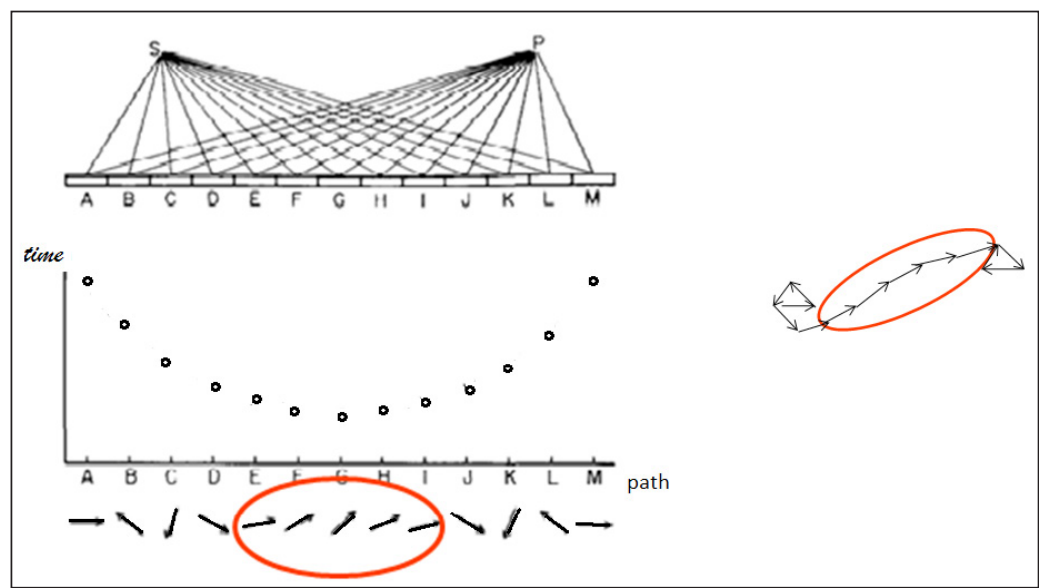

Figure 4: Analysis of some paths that could be reflected by the mirror, the associated vectors and the sum for the reflection in a mirror. With a red oval, the contributions to the sum are stand out.

A second simulation was created with the software Modellus ${ }^{T M}$ to analyze reflection. Here students can choose different possible paths connecting the source with the detection point, and add them to obtain the amplitude of probability. There are two relevant aspects to consider.

Firstly the least time path is the most probable, since around this one neighboring paths contribute with almost same phase (red ellipse in Figure 4). This is consistent with the Fermat least time principle of geometrical optics.

Secondly, quantum mechanics go beyond Fermat principle, and states that the least time path is the most probable but not the only one possible. In other words it predicts reflexion at points that violate incidence angle $=$ reflection angle. This was also analyzed with this simulation, although it is not shown here.

b) Refraction law

From Figure 5 it is possible to analyse with the students the paths, the sums and to conclude that the most probable path for the light crossing air to water is one whose time trip is minimal. For that path, the angle of refraction varies with respect to the angle of incidence such as the time is minimal, instead of the length of the path. 
PROBLEMS

OF EDUCATION

IN THE $21^{\text {st }}$ CENTURY

Volume 47, 2012

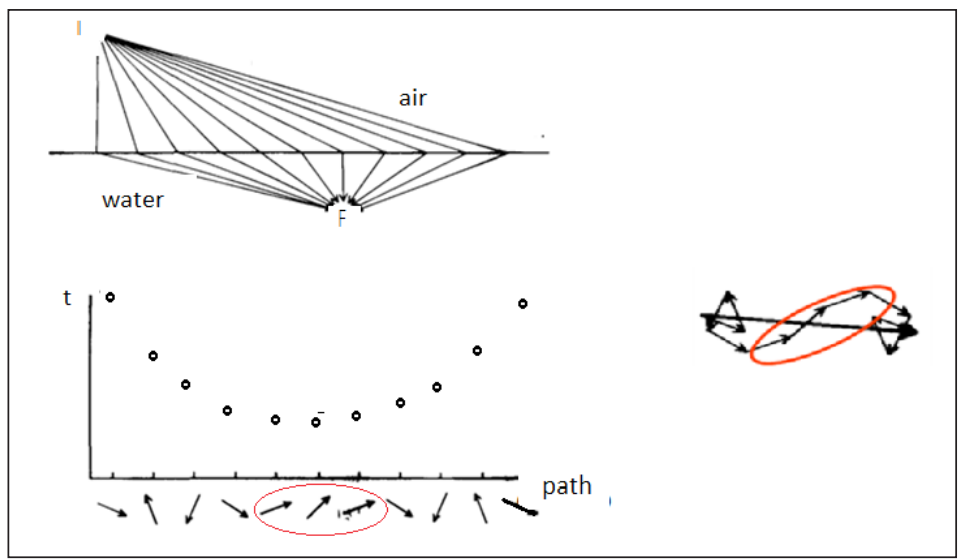

Figure 5: Analysis of some paths, the associated vectors and the sum for the refraction. With a red oval, the contributions to the sum were stand out.

Here, another simulation with the software Modellus ${ }^{T M}$ has been performed. The students can choose different possible paths connecting the source to the detect point, when the light pass from the air to the water. For each path selected the simulation shows the associated vector, and the students have to make the sum of them for to find a description of the refraction phenomena experimentally observed, using the framework of the alternative paths of Feynman.

c) Explaining the individual detections and the pattern of the double slit experience using the Feynman method:

The proposal to the students is to analyze the double slit experience, considering the individual detections of the light. Remembering that initially the detections of the light seemed to be random, but with the time, one began to notice a distribution: there were some places where there was a great quantity of detections, and places where it had not, or there were very few ones, detections of light. The question asked to the students is: How calculate the probability of detecting the light for every place of the screen? The method of considering the alternative paths of the quantum mechanics must be used. The scheme of the experience showed in Figure 6 allows calculating the probability of detecting light in a certain place of the screen, to a certain distance, let's say $x$, of the center of the screen:

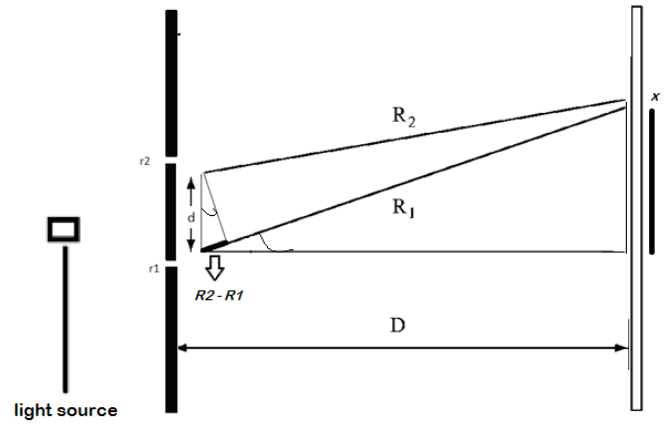

Figure 6: The paths, the associated vectors and the sum for the double slit experience. 
The vectors contributing for the probability, are those identified with the direct paths IN THE $21^{\text {st }}$ CENTURY (which time is minimal) and a finite set of vectors associated with the nearby ways, let's say " $n$ ". That is to say, in the calculus of the probability there will be necessary to consider $n$ times the vector which angle is proportional to the minimal time, to the square:

$$
\overrightarrow{V_{1}\left(r_{1} \rightarrow x\right)} \overrightarrow{V_{1}\left(r_{1} \rightarrow x\right)}=\mathrm{N}\left(1 ; k . t_{1}\right)
$$

Where $k$ is a proportional constant (in fact, $k=2 \pi f$ but with the students is better do not use the term frequency because it is a term proper of the ondulatory model) and $t$ is the time to go from slit 1 to the detection screen. In Cartesian coordinates:

$$
\overrightarrow{V_{1}\left(r_{1} \rightarrow x\right)}=n\left(\cos \left(k t_{1}\right) ; \sin \left(k t_{1}\right)\right)
$$

Analogous for the other slit:

$$
\overrightarrow{V_{2}\left(r_{2} \rightarrow x\right)}=n\left(\cos \left(k t_{2}\right) ; \sin \left(k t_{2}\right)\right)
$$

Now, the sum of both vectors must be done for to obtain the total amplitude:

$$
\begin{aligned}
\overrightarrow{\operatorname{Sum} P(x)}= & \overrightarrow{V_{1}\left(\mathrm{r}_{1} \rightarrow \mathrm{x}\right)}+\overrightarrow{V_{2}\left(\mathrm{r}_{2} \rightarrow \mathrm{x}\right)} \\
& =N((\cos (k t 1) ; \operatorname{sen}(k t 1))+N((\cos (k t 2) ; \operatorname{sen}(k t 2))
\end{aligned}
$$

Realizing the sum of the vectors, and then raising the result to the square, the following expression is obtained for the detection of the probability in certain place $x$ of the center of the screen:

$$
P(x) \propto \cos ^{2}\left(\frac{k t_{2}-k t_{1}}{2}\right)
$$

Expressing the probability in function of the geometry situation, and replacing the time for each case: $\mathrm{t}_{2}=\mathrm{R}_{2} / \mathrm{c}$ y $\mathrm{t}_{1}=\mathrm{R}_{1} / \mathrm{c}$. Then, $k \mathrm{t}_{2}-k \mathrm{t}_{1}=\mathrm{R}_{2} / \mathrm{c}-\mathrm{R}_{1} / \mathrm{c}=\left(\mathrm{R}_{2}-\mathrm{R}_{1}\right) / \mathrm{c}$ (see schema of the experience)

Then the final expression is:

$$
P(x) \propto \cos ^{2}\left(\frac{R_{2}-R_{1}}{2 c}\right)
$$

Making more geometric considerations and expressing the path difference $R_{2}-R_{1}$ like a function of the separation between the silts (d) and the distance between the screen $\mathrm{D}$. Therefore, considering that $\mathrm{D}>>\mathrm{d}$ :

$$
R_{2}-R_{1}=\frac{x}{D} d
$$

Replacing this expression in the equation of $\mathrm{P}(x)$ :

$$
\mathrm{P}(x) \sim \cos ^{2}\left(\frac{k d}{2 c D} \cdot x\right)
$$

This is the expression of the probability

to detect light to a distance $x$ to the 
PROBLEMS

OF EDUCATION

IN THE $21^{\text {st }}$ CENTURY

Volume 47, 2012

36

centre of the screen. This is the prediction of the quantum mechanics. It must be analyzed if it is the same that is obtained from the experience. The previous expression of $P(x)$ allows concluding that the probability function has maxima and minima, and so, these are the maxima and minima noted on the screen.

\section{Conclusions}

An alternative method for teaching the basics and fundamental concepts of QM was presented and a sequence of teaching situations focused on the behavior of the light was designed. This sequence seems a good teaching strategy because the concepts and principles of quantum mechanics are directly approached using physical experiences, questions and problems. For instance, is very important to show that it is not possible to associate the light with purely ondulatory or purely corpuscular aspects and therefore it is not possible to reconcile the concept of light completely with everyday concepts of wave or particle.

This proposal has been successfully implemented with two groups of students of the secondary school (15-16 years old), of two different schools. At the moment, the data are being analyzed, but it is possible to conclude that the sequence of situations proposed was viable because the students have reconstructed the fundamental notions of the quantum mechanics, and they have well arrived at the end of the sequence. They accepted the challenges and the proposed problems; they realized the experiences in the classes and they interpreted them; they used the simulations supported by Modellus ${ }^{M T}$ and they made adequate conclusions of the nature of the light.

\section{Notes}

1- The Double slit experience with very low intensity light online is available in http://www.youtube.com/watch?v=MbLzh1Y9POQ

2-The course is available at http://advancingphysics.iop.org/about the_course/as_course.html (Chapter 7. Quantum Behaviour)

\section{Acknowledgments}

National Council of Scientific and Technical Researches. (CONICET). http://www.conicet.gov. ar/

Nucleus of Research in Education in Science and Technology (NIECyT). Faculty of Exact Sciences, National University of the Center of the Province of Buenos Aires (UNCPBA).

\section{References}

Arlego, M., Fanaro, M. A, Otero, M. R (2012). Teaching different aspects of light in the unified framework of quantum mechanics. Abstracts of the World Conference on Physics Education, Julio 2012. Istanbul, Turkey.

Bosch, M., García, F., Gascón, J., Ruiz Higueras, L. (2006). La modelización matemática y el problema de la articulación de la matemática escolar. Una propuesta desde la teoría antropológica de lo didáctico. Educación Matemática, 18, (2), 37-74.

Chevallard, Y. (1992). Concepts fondamentaux de la didactique: Perspectives apportées par une approche anthropologique. Recherches en Didactique des Mathématiques, 12 (1), 73-112. 
Maria de los ÁNGELES FANARO, Maria Rita OTERO, Marcelo ARLEGO. A Proposal to Teach Light in a Unified Framework Using the Feynman Method

$\mid$\begin{tabular}{l} 
PROBLEMS \\
OF EDUCATION \\
IN THE 21 $1^{\text {st }}$ CENTURY \\
Volume 47, 2012 \\
\hline 37
\end{tabular}

Chevallard, Y. (1997). Familière et problématique, la figure du professeur. Recherches en Didactique des Mathématiques, 17 (3), 17-54.

Chevallard, Y. (1999). L'analyse des practiques enseignantes en théorie anthropologique du didactique. Recherches en Didactique des Mathématiques, 19 (2), 221-265.

Cuppari, A., Rinaudo, G., Robutti, O., Violino, P. (1997). Gradual introduction of some aspects of quantum mechanics in a high school curriculum. Physics Education, 32, 302-308.

Fanaro, M. A., Arlego, M., Otero, M. R. (2011). Análisis de la conceptualización de un grupo de estudiantes de escuela secundaria al abordar situaciones de Mecánica Cuántica. Actas del I Congreso Internacional en Enseñanza de las Ciencias y la Matemática- II Encuentro Nacional en Enseñanza de la Matemática.

Fanaro, M. A., Otero, M. R., Arlego, M. (2012). Teaching Basic Quantum Mechanics in Secondary School Using Concepts of Feynman's Path Integrals Method. The Physics Teacher, 50 (3), 156-158.

Fanaro, M., Otero, M. R., Arlego, M. A. (2009). Teaching the foundations of quantum mechanics in secondary school: a proposed conceptual structure. Investigações em Ensino de Ciências, 14 (1), 37-64.

Feynman, R. (1985). QED The strange theory of light and matter. Penguin Books. Princeton University Press, USA, $158 \mathrm{p}$

Fischler, H., Lichtfeldt, M. (1992). Modern Physics and students' conceptions. International Journal of Science education, 14 (2), 181-190.

González, E., Fernández, P., Solbes, J. (2000). Dificultades de docentes de ciencia en la conceptualización de temas de física actual. Actas del V Simposio de Investigación en Educación en Física, Tomo 1.138-147. Argentina.

Greca, I., Moreira, M. A. (2004). Obstáculos representacionales mentales en el aprendizaje de conceptos cuánticos. In Moreira, M A. (2003) Sobre el cambio conceptual, obstáculos representacionales, modelos mentales, esquemas de asimilación y campos conceptuales. (pp. 26-40) Instituto de Física. UFRGS, Brasil.

Greca, I., Moreira, M. A., Herscovitz, V. (2001). Uma Proposta para o Ensino de Mecânica Quântica. Revista Brasileira de Ensino de Física, 23 (4), 444-457.

Hanc, J. (2006). The time-independent Schrödinger equation in the frame of Feynman's version of quantum mechanics. Proceedings $10^{\text {th }}$ Workshop on Multimedia in Physics. Teaching and Learning. Berlin. Available in http://titan.physx.u-szeged.hu/ mpt111/Proceedings/HancSzeged2006.pdf

Hanc, J., Taylor, E., Tuleja, S. (2004). Report on some results from the 2004 Gordon Conference on Classical Mechanics and Nonlinear Systems. Proceedings $9^{\text {th }}$ Multimedia in Physics Teaching and Learning. Available in http://physik.uni-graz.at/MPTL9/proceedings/ProcHanc.pdf

Hanc, J., Tuleja, S. (2005). The Feynman Quantum Mechanics with the help of Java applets and physlets in Slovakia. Proceedings $10^{\text {th }}$ Workshop on Multimedia in Physics. Teaching and Learning. Berlin. Available at http://physedu.science.upjs.sk/modelovanie/files/hanc_berlin_2005.pdf

Hanc, J., Taylor, E. F. (2004). From Conservation of Energy to the Principle of Least Action: A Story Line. American Journal of Physics, 72 (4), 514-521.

Lobato, T., Greca, I. (2005). Analise da inserção de conteúdos de teoria quântica nos currículos de física do ensino médio. Ciencia \& Educación, 11 (1), 119-132.

Montenegro, R. L., Pessoa, Jr. O. (2002). Interpretações da teoria quântica e as concepções dos alunos do curso de física. Investigações em Ensino de Ciências, 7 (2), Available online at: http://www. if.ufrgs.br/public/ensino/revista.htm

Moreira, M. A., Greca, I. (2000). Introdução a Mecânica Quântica: seria o caso de evitar a aprendizagem significativa (subordinada)? Proceedings of II ENPEC (CDROM). 
PROBLEMS

OF EDUCATION

IN THE $21^{\text {st }}$ CENTURY

Volume 47, 2012

38

Ogborn, J. (2006). A First Introduction to Quantum Behavior The Girep conference 2006, Modeling in Physics and Physics Education, Universiteit van Amsterdam. Available online at: http://www. eftaylor.com/pub/ActionSummary.pdf

Ogborn, J. Hanc, F. J., Taylor, E. (2006). Action on Stage: Ways to Unify Classical and Quantum Physics Using the Action Model. Proceedings The Girep conference 2006, Modeling in Physics and Physics Education, Universiteit van Amsterdam. Available online at: http://home.medewerker. uva.nl/o.slooten/bestanden/Girep\%20Proceedings\%20CD.pdf

Osterman, F., Moreira, M. (2000). Uma revisão bibliográfica sobre a área de pesquisa física moderna e contemporânea no ensino médio. Investigações em ensino de ciências, 5 (1). http://www.if.ufrgs. br/public/ensino/vol5/n1/v5_n1_a2.htm

Osterman, F., Ricci, T. (2004). Construindo uma unidade didática conceitual sobre mecânica quântica: um estudo na formação de professores de fisica. Ciencia \& Educação, 10, (2) 235-257. Http://www. sbfisica.org.br/fne/Vol7/Num1/v12a07.pdf

Osterman, F., Prado, S., Ricci, T. (2006). Desenvolvimento de um software para o ensino de Fundamentos de Física Quântica. A Física na Escola, 7 (1), 22-25.

Osterman, F., Prado, S., Ricci, T. (2008). Investigando A Aprendizagem De Professores De Física Acerca Do Fenômeno Da Interferência Quântica. Ciência \& Educação, 14 (1) 35-54.

Otero, M. R., Fanaro, M. A. (2011). Physics Didactic, Affects and Conceptualization. Review of Science, Mathematics and ICT Education, 5 (2), 5-26.

Otero, M. R. (2006). Emociones, sentimientos y razonamientos en Didáctica de las Ciencias. Revista Electrónica de Investigación en Educación en Ciencias. Available in http://www.exa.unicen.edu. ar/reiec/

Otero, M. R., Fanaro, M. A., Arlego, M. (2009). Investigación y desarrollo de propuestas didácticas para la enseñanza de la Física en la Escuela Secundaria: Nociones Cuánticas. Revista Electrónica de Investigación en Educación en Ciencias, 4 (1), 58-74.

Paulo, I. J. C., Moreira, M. A. (2005). Um Estudo Sobre A Captação Do Significado Do Conceito De Dualidade Onda-Partícula Por Alunos Do Ensino Médio Enseñanza de las Ciencias, Número extra.

Paulo, I. J. C., Moreira, M. A. (2004). Abordando conceitos fundamentais da mecânica quântica no nivel médio. Actas II Encuentro Iberoamericano sobre Investigación Básica en Enseñanza de las Ciencias, España.

Paulo, I. J. C. (2006). A Aprendizajem Significativa Crítica de Conceitos da Mecânica Quântica Segundo a Interpretação de Copenhagen e o Problema da Diversidade de Propostas de Inserção da Física Moderna e Contemporânea no Ensino Médio. Tesis Doctoral.

Pessoa, Jr, O. (1997). Interferometria, interpretação e intuição: uma introdução conceitual à Física Quântica. Revista Brasileira de Ensino de Física, 19 (1), 27-47.

Pinto, A. C., Zanetic, J. (1999). É possível levar a Física Quântica para o Ensino Médio? Caderno Catarinense de Ensino de Física, 16 (1), 7-34.

Taylor, E., Stamatis, V., O’Meara, J. M., Thornber, N. (1998). Teaching Feynman's Sum Over Paths Quantum Theory. Computers in Physics, 12, 190-199.

Taylor, E. (2000). Desmityfing QM. Quantum Mechanics Workbook. Available in http://www.eftaylor. com

Taylor, E. (2003). A call to action. American Journal of Physics, 71 (5), 423-425.

Taylor, F., Stamatis V., O’Meara, J., Hornberd, N. (1998). Teaching Feynman's sum-over-paths quantum theory. Computers in Physics, 12 (2), 190-199. 
Maria de los ÁNGELES FANARO, Maria Rita OTERO, Marcelo ARLEGO. A Proposal to Teach Light in a Unified Framework Using the Feynman Method

PROBLEMS

OF EDUCATION

IN THE $21^{\text {st }}$ CENTURY

Volume 47,2012

Vergnaud, G. (1990). La théorie des champs conceptuels. Recherches en Didactique des Mathématiques, $10(2 / 3), 133-170$.

Advised by Laima Railiene, University of Siauliai, Lithuania

Received: September 20, 2012

Accepted: November 07, 2012

\begin{tabular}{|ll|}
\hline Maria de los Ángeles Fanaro & $\begin{array}{l}\text { Ph.D in Science Education, University of Burgos, Spain. Nucleus of } \\
\text { Research in Education in Science and Technology. Teachers' formation De- } \\
\text { partment, Faculty of Exact Sciences, National University of the Center of the } \\
\text { Province of Buenos Aires (UNCPBA), Assistant Researcher of the National } \\
\text { Council of Scientific and Technical Researches. (CONICET), Argentina. } \\
\text { E-mail: mfanaro@exa.unicen.edu.ar } \\
\text { Website: http://mariaangelesfanaro.sites.exa.unicen.edu.ar/ }\end{array}$ \\
\hline Maria Rita Otero & $\begin{array}{l}\text { Ph.D in Science Education, University of Burgos, Spain. Nucleus of } \\
\text { Research in Education in Science and Technology, Teachers' formation } \\
\text { Department, Faculty of Exact Sciences, National University of the Center } \\
\text { of the Province of Buenos Aires (UNCPBA). Independent researcher of } \\
\text { the National Council of Scientific and Technical Researches (CONICET), } \\
\text { Argentina. } \\
\text { E-mail: rotero@exa.unicen.edu.ar } \\
\text { Website: https://sites.google.com/site/mariaritaotero/ }\end{array}$ \\
\hline Marcelo Arlego & $\begin{array}{l}\text { Ph.D in Physics, National University of La Plata. Institute of Physics la Plata } \\
\text { (IFLP), UNLP. }\end{array}$ \\
Assistant Researcher of the National Council of Scientific and Technical \\
Researches, (CONICET), Argentina. \\
E-mail: arlego@fisica.unlp.edu.ar
\end{tabular}

